\title{
Association of the functional capacity and violence in the elderly community
}

\author{
Associação da capacidade funcional e violência em idosos comunitários \\ Relación de la capacidad funcional y violencia en ancianos comunitarios
}

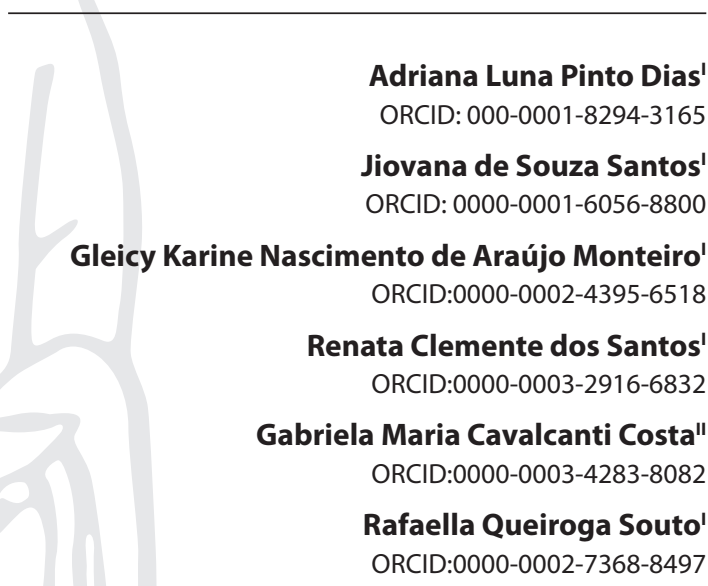

'Universidade Federal da Paraíba. João Pessoa, Paraíba, Brazil. "Universidade Estadual da Paraíba. Campina Grande, Paraíba, Brazil.

How to cite this article: Dias ALP, Santos JS, Araújo-Monteiro GKN, Santos RC, Costa GMC, Souto RQ. Association of the functional capacity and violence in the elderly community.

Rev Bras Enferm. 2020;73(Suppl 3):e20200209. doi: http://dx.doi.org/10.1590/0034-7167-2020-0209

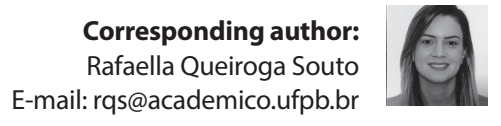

EDITOR IN CHIEF: Antonio José de Almeida Flho ASSOCIATE EDITOR: Ana Fátima Fernandes

Submission: $03-30-2020$

Approval: 06-14-2020

\begin{abstract}
Objective: To analyze the relationship between the functional capacity of elderly community members and the sociodemographic and violence characteristics. Methods: Cross-sectional, epidemiological, analytical study with 159 elderly people. For data collection, a questionnaire was used for sociodemographic characterization; the Katz, Lawton and Brody scale; a questionnaire adapted from the FIBRA network; and the Conflict Tactics Scales, analyzed using descriptive and inferential statistics using Pearson's chi-square test, Fisher's exact test and multiple logistic regression models. Results: It was observed that the sociodemographic variables influence the prevalence of functional dependence for basic activities of daily living and reduction in advanced activities in elderly people with psychological and physical violence. Conclusion: The dependence of the elderly for basic and intermediate activities is related to characteristics such as advanced age, work exercise and knowing how to read and write. The participants' functional dependence can favor violent outcomes, whether physical or psychological.
\end{abstract}

Descriptors: Aged; Violence; Elder Abuse; Activities of Daily Living; Geriatric Nursing.

\section{RESUMO}

Objetivo: Analisar a relação da capacidade funcional de idosos comunitários com as características sociodemográficas e de violência. Métodos: Estudo epidemiológico transversal, do tipo analítico, com 159 idosos. Para coleta dos dados, utilizaram-se um questionário para caracterização sociodemográfica; a escala de Katz, de Lawton e Brody; um questionário adaptado da rede FIBRA; e a Conflict Tactics Scales, analisados mediante estatística descritiva e inferencial por meio do teste qui-quadrado de Pearson, teste exato de Fisher e modelos de regressão logística múltipla. Resultados: Observou-se que as variáveis sociodemográficas influenciam a prevalência da dependência funcional para as atividades básicas da vida diária e redução nas atividades avançadas em idosos com violência psicológica e física. Conclusão: A dependência de idosos para atividades básicas e intermediárias relacionase com características como idade avançada, exercício laboral e saber ler e escrever. A dependência funcional dos participantes pode favorecer desfechos violentos, sejam eles físicos, sejam psicológicos.

Descritores: Idoso; Violência; Maus-Tratos ao Idoso; Atividades Cotidianas; Enfermagem Geriátrica.

\section{RESUMEN}

Objetivo: Analizar la relación de la capacidad funcional de ancianos comunitarios con las características sociodemográficas y de violencia. Métodos: Estudio epidemiológico transversal, del tipo analítico, con 159 ancianos. Para recogida de los datos, se utilizaron un cuestionario para caracterización sociodemográfica; la escala de Katz, de Lawton y Brody; un cuestionario adaptado de la red FIBRA; y la Conflict Tactics Scales, analizados mediante estadística descriptiva y inferencial por medio del test chi cuadrado de Pearson, test exacto de Fisher y modelos de regresión logística múltipla. Resultados: Se observó que las variables sociodemográficas influencian la prevalencia de la dependencia funcional para las actividades básicas de la vida diaria y reducción en las actividades avanzadas en ancianos con violencia psicológica y física. Conclusión: La dependencia de ancianos para actividades básicas y intermediarias se relaciona con características como edad avanzada, ejercicio laboral y saber leer y escribir. La dependencia funcional de los participantes puede favorecer desfechos violentos, sean ellos físicos, sean psicológicos.

Descriptores: Anciano; Violencia; Maltrato al Anciano; Actividades Cotidianas; Enfermería Geriátrica. 


\section{INTRODUCTION}

Population aging advances in the Brazilian scenario. In 2019, the number of people over 65 years old corresponded to approximately 20 million, totalling $9.52 \%$ of the country's population. It is estimated that this population will reach, in 2060 , the percentage of $25.49 \%$, equivalent to about 58 million individuals in this age group ${ }^{(1)}$.

Changes in population structure have an impact on the population's morbidity profile, with the increase in the incidence of non-communicable diseases on transmissible processes. Affection by chronic non-communicable diseases (NCDs) is associated with a decrease in functional capacity, reflecting in the limitation of the performance of activities of daily living $(A D L)^{(2)}$.

Functional capacity is represented by the potential to maintain the physical and mental functions necessary to preserve autonomy and independence. It is one of the most relevant dimensions in gerontology, due to personal and family suffering, resulting from dependence and growing demand for social and health services ${ }^{(3)}$.

Functional capacity involves the performance of ADLs, whether basic, instrumental and advanced. The basic activities of daily living (BADLs) are those related to self-care, such as bathing and dressing ${ }^{(4)}$. The instrumental activities of daily living (IADLs) include the performance of functions necessary to maintain an independent life in the community, such as using the phone and shopping ${ }^{(5)}$. Advanced activities of daily living (AADLs) are those related to the physical, social, productive and leisure domains ${ }^{(6)}$.

The impairment of functional capacity and dependence are considered vulnerability factors with a strong level of evidence for the manifestation of violence in the elderly ${ }^{(7)}$, being also related to signs of violence in these people $e^{(8)}$.

Violence against the elderly is a worldwide phenomenon, defined by the World Health Organization (WHO) $)^{(9)}$ as a "single or repeated act, or lack of appropriate action, occurring in any relationship where there is an expectation of trust, which causes harm or suffering to an elderly person". A global estimate reveals that $6 \%$ of the elderly have been victims of violence, and the number of elderly people vulnerable to it is projected to increase ${ }^{(10)}$.

In Brazil, it appears that the residence of the elderly is the main locus of the violent experience. However, it is known that many elderly people do not report their dependence on third parties, fear of the consequences or fear of negatively affecting their relationships and family integrity, since children and spouses represent more than half of the aggressors ${ }^{(11-12)}$.

In this context, considering the significant number of elderly people and the reduction in functional capacity, it is relevant to study its relationship with violence in the elderly. In this way, it will be possible to contribute to the elaboration of public policies and intervention protocols that support actions of social and health services, favoring innovations in care and preserving the subjects' independence. Consequently, it is possible to prevent situations of violence and improve the living conditions of this population.

\section{OBJECTIVE}

To analyze the functional capacity of elderly community members and their relationship with sociodemographic characteristics and the outcome of violence.

\section{METHODS}

\section{Ethical aspects}

This study is linked to the research entitled "Impact of multidimensional interventions on elderly registered in Primary Health Care and their caregivers", approved by the Research Ethics Committee of the Health Sciences Center (CCS) of the Universidade Federal de Pernambuco (UFPE).

\section{Study design, period and location}

Cross-sectional epidemiological study, analytical type, guided by the STROBE Initiative, carried out from March 2016 to March 2017, in three Basic Family Health Units, in micro-region III of Sanitary District IV in the municipal of Recife, Pernambuco, Brazil.

\section{Population or sample; inclusion and exclusion criteria}

The number of elderly people in each team was determined by the proportionality between the three health units. The population was composed of 1,209 elderly people, with sample calculation using the finite population formula for epidemiological studies, adopting an error power of $8 \%$. The sample selection was random, proportional, systematic, considering that, for every five elderly individuals on the list of each team, one was selected and invited to participate in the research.

The study included people classified as elderly and who were registered in the area enrolled in that health unit. Those with communication difficulties or severe cognitive impairment were excluded, and these criteria were identified by the researcher at the time of collection or referred by the caregiver.

During the research, 176 elderly people were approached to contribute to the study for meeting the eligibility criteria, however 17 were excluded due to the impossibility of carrying out the collection. Then, the sampling strategy was followed, and the next elderly person on the list was invited to participate. Thus, the sample was composed of 159 participants.

\section{Study protocol}

The data collection team consisted of 22 students from the Nursing course and 11 from the Occupational Therapy course. Two training sessions were carried out to calibrate the collectors, discussing the instruments to be used and the ethical rigor of scientific research.

The interviewers carried out the collection accompanied by the community health agents ( $\mathrm{CHA}$ ), aiming to articulate the bond with the elderly and the safety of the collector. This stage took place at the residence of the elderly after clarification about the objectives and voluntary participation in the research, the confidentiality of the information provided and after signing the Free and Informed Consent Term (ICF). Initially, a pilot study was carried out with 25 elderly people, later included in the final sample, to assess the feasibility of the collection and the instrument and, thus, minimize failures.

A questionnaire prepared by the researcher for sociodemographic characterization; the Katz index for BADLs ${ }^{(4) ;}$ Lawton's scale for assessing IADLs $s^{(5)}$; a questionnaire adapted from the network "Frailty in Elderly Brazilians" (FIBRA) for AADLs ${ }^{(13)}$; and the Conflict Tactics 
Scales Form R (CTS-1) to assess the existence of violence, in its physical and psychological dimensions were used for data collection ${ }^{(14)}$.

The Katz index assesses the functional capacity for BADLs, considering six activities of hierarchical complexity: feeding, sphincter control, transfers, abilities to dress, bathe and use the toilet $^{(15)}$. The elderly who did not need help in any of the activities were classified as independent; and dependents, those who needed help in more than one activity.

The Lawton and Brody scale ${ }^{(5)}$ evaluates IADLs, comprising the following activities: preparing meals, performing household chores, handling money, using the telephone, taking medications, shopping and using means of transport. The scale classifies the functional condition of the elderly through a score involving the seven activities ${ }^{(16)}$. They were classified as independent when the score reached 21 points; or dependent, with a score of up to 20 points.

In assessing AADLs, a set of questions from the FIBRA network adapted by Oliveira et al. ${ }^{(13)}$. The questions address the engagement of the elderly in 13 activities distributed in educational, civic, religious and leisure domains, enabling three response options: "never did", "stopped doing" and "still does". The most active (MA) were those who performed four or more activities; and less active (LA), the elderly who developed three or less activities.

CTS-1 aims to measure the strategies used by family members to resolve possible conflicts and, indirectly, to perceive situations of violence. This scale consists of 19 questions that are divided into three groups, according to the types of strategies used to deal with disagreements: argumentation (items a-c), verbal aggression (items d-f and $\mathrm{h}-\mathrm{j}$ ) and physical aggression (items k-s). Each item includes three answer options: "it didn't happen", "it happened a few times in the last 12 months" and "it happened several times in the last 12 months"(17).

For the classification of violence, the items of verbal aggression assess psychological violence; acts such as pushing, grabbing, slapping, throwing objects, twisting the arm and pulling the hair identify minor physical violence; and greater physical violence comprises the most serious items of the instrument, such as punching, hitting, kicking, throwing against the wall, burning or scalding, using a knife or firearm. The elderly person who presented a positive response in any of the items was considered to be in a situation of violence, according to each classification ${ }^{(17)}$.

\section{Analysis of results and statistics}

The data were tabulated and analyzed using SPSS, version 25.0, using descriptive statistics (absolute and relative frequency) and inferential statistics (Pearson's chi-square test, Fisher's exact test and multiple logistic regression models). Fisher's exact test was chosen in cases where the number of cells with a frequency below $5 \%$ was less than $20 \%$.

The entry criterion for the variables for the logistic regression model was defined among the variables that presented $p<0.2$. For all analyzes, a significance level of $5 \%(p<0.05)$ was adopted.

\section{RESULTS}

Regarding the characterization of the elderly, 53.5\% ( $\mathrm{n}=$ $85)$ are aged between 60 and 70 years, $76.7 \%(n=122)$ being female, $66 \%(n=105)$ without a partner (widows, divorced or never married), $79.2 \%(n=126)$ do not work and $71.1 \%(113)$ have an average income of one minimum wage, in force at the time of collection.

Sociodemographic variables were associated with functional capacity through BADLs, IADLs and AADLs, as shown in Table 1. It was found that there was an association between sex ( $p$ $=0.031)$ and marital status $(p=0.006)$ with BADLs. It was also observed that the variables age, knowing how to read and write, marital status and work activity were associated with IADLs ( $p$ $<0.001 ; p<0.001 ; p=0.011 ; p=0.003$, respectively). Considering the functional capacity to perform advanced activities of daily living, there was an association with age, knowing how to read and write, marital status and work activity $(p<0.001 ; p=0.018$; $p=0.030 ; p=0.002$, respectively).

The analysis of functional capacity did not show associations with psychological, minor and major physical violence. Functional dependence for BADLs predominated in the elderly with psychological (18.2\%; $n=10)$, minor physical $(28.6 \% ; n=02)$ and major physical $(25.0 \% ; n=01)$. On the other hand, for IADLs, functional dependence prevailed in the elderly without any type of violence. As for the AADLs, elderly people under psychological violence $(50.9 \% ; n=28)$, minor physical violence $(57.1 \% ; n=04)$ and greater physical $(75.0 \% ; n=03)$ were considered less active. These results can be seen in Table 2 .

Table 1 - Distribution of the sociodemographic profile of the elderly according to functional capacity, Recife, Pernambuco, Brazil, 2016-2017

\begin{tabular}{|c|c|c|c|c|c|c|}
\hline \multirow[b]{2}{*}{ Variables } & \multicolumn{2}{|c|}{ BADLs } & \multicolumn{2}{|c|}{ IADLs } & \multicolumn{2}{|c|}{ AADLs } \\
\hline & $\begin{array}{c}D \\
\text { n (\%) }\end{array}$ & $\begin{array}{c}\text { I } \\
\text { n (\%) }\end{array}$ & $\begin{array}{c}\text { D } \\
\text { n (\%) }\end{array}$ & $\begin{array}{c}\text { I } \\
\text { n (\%) }\end{array}$ & $\begin{array}{c}\text { LA } \\
\text { n (\%) }\end{array}$ & $\begin{array}{c}\text { MA } \\
\text { n (\%) }\end{array}$ \\
\hline \multicolumn{7}{|l|}{ Age } \\
\hline $60-70$ years & $12(14)$ & 74 (86.9) & $33(38.8)$ & $52(61.2)$ & $30(34.9)$ & $56(65.1)$ \\
\hline$>70$ years & 15 (28.8) & 57 (79.2) & $52(71.2)$ & $21(28.8)$ & $45(61.6)$ & $28(38.4)$ \\
\hline$p$ value & \multicolumn{2}{|c|}{$0.253^{*}$} & \multicolumn{2}{|c|}{$<0.001 *$} & \multicolumn{2}{|c|}{$<0.001 *$} \\
\hline \multicolumn{7}{|l|}{ Sex } \\
\hline Male & $2(5.4)$ & 35 (94.6) & $20(54.1)$ & $17(45.9)$ & $15(40.5)$ & $22(59.5)$ \\
\hline Female & 25 (20.7) & 96 (79.3) & 65 (53.7) & $56(46.3)$ & $60(49.2)$ & $62(50.8)$ \\
\hline$p$ value & \multicolumn{2}{|c|}{$0.031 *$} & \multicolumn{2}{|c|}{$0.971^{*}$} & \multicolumn{2}{|c|}{$0.356^{*}$} \\
\hline \multicolumn{7}{|c|}{ Can read and write } \\
\hline Yes & $14(13.2)$ & $92(86.8)$ & $42(40.0)$ & $63(60)$ & $43(40.6)$ & $63(59.4)$ \\
\hline No & $13(25.0)$ & $39(75.0)$ & $43(81.1)$ & $10(18.9)$ & $32(60.4)$ & $21(39.6)$ \\
\hline$p$ value & \multicolumn{2}{|c|}{$0.064 *$} & \multicolumn{2}{|c|}{$0.001 *$} & \multicolumn{2}{|c|}{$0.018^{*}$} \\
\hline
\end{tabular}




\begin{tabular}{|c|c|c|c|c|c|c|}
\hline \multirow[b]{2}{*}{ Variables } & \multicolumn{2}{|c|}{ BADLs } & \multicolumn{2}{|c|}{ IADLs } & \multicolumn{2}{|c|}{ AADLs } \\
\hline & $\begin{array}{c}D \\
\text { n (\%) }\end{array}$ & $\begin{array}{c}\text { I } \\
\text { n (\%) }\end{array}$ & $\begin{array}{c}\text { D } \\
\text { n (\%) }\end{array}$ & $\begin{array}{c}\text { I } \\
\text { n (\%) }\end{array}$ & $\begin{array}{c}\text { LA } \\
\text { n (\%) }\end{array}$ & $\begin{array}{c}\text { MA } \\
\text { n (\%) }\end{array}$ \\
\hline \multicolumn{7}{|l|}{ Marital status } \\
\hline With companion & $3(5.6)$ & $51(94.4)$ & $21(39.6)$ & $32(60.4)$ & $19(35.2)$ & $35(64.8)$ \\
\hline Without companion & $24(23.1)$ & $80(76.9)$ & $64(61.0)$ & $41(39.0)$ & $56(53.3)$ & $49(46.7)$ \\
\hline$p$ value & \multicolumn{2}{|c|}{$0.006^{*}$} & \multicolumn{2}{|c|}{$0.011^{*}$} & \multicolumn{2}{|c|}{$0.030^{*}$} \\
\hline \multicolumn{7}{|l|}{ Home } \\
\hline Live alone & $4(18.2)$ & $18(81.8)$ & $11(50.0)$ & $11(50.0)$ & $12(54.5)$ & $10(45.5)$ \\
\hline Live with someone & $23(16.9)$ & $113(83.1)$ & $74(54.4)$ & $62(45.6)$ & $63(46.0)$ & $74(54.0)$ \\
\hline$p$ value & \multicolumn{2}{|c|}{$0.543^{* *}$} & \multicolumn{2}{|c|}{$0.700^{*}$} & \multicolumn{2}{|c|}{$0.455^{*}$} \\
\hline \multicolumn{7}{|l|}{ Physical work activity } \\
\hline Yes & $2(7.4)$ & $25(92.6)$ & $7(25.9)$ & $20(74.1)$ & $5(18.5)$ & $22(81.5)$ \\
\hline No & $22(17.6)$ & $103(82.4)$ & $72(57.6)$ & $53(42.4)$ & $65(51.6)$ & $61(48.4)$ \\
\hline$p$ value & \multicolumn{2}{|c|}{$0.252^{* *}$} & \multicolumn{2}{|c|}{$0.003^{*}$} & \multicolumn{2}{|c|}{$0.002^{*}$} \\
\hline \multicolumn{7}{|l|}{ Income } \\
\hline Up to one minimum salary & 20 (17.9) & $92(82.1)$ & $65(58.0)$ & $47(42.0)$ & $57(50.4)$ & $56(49.6)$ \\
\hline More than one minimum salary & $7(15.2)$ & $39(84.8)$ & $20(43.5)$ & $26(56.5)$ & $18(39.1)$ & $28(60.9)$ \\
\hline$p$ value & \multicolumn{2}{|c|}{$0.689^{*}$} & \multicolumn{2}{|c|}{$0.095^{*}$} & \multicolumn{2}{|c|}{$0.195 *$} \\
\hline
\end{tabular}

Note: * Pearson's chi-square test; ** Fisher's exact test; D-Dependent; I Independent; MA- more active; LA - less active; Basic activities of daily living (BADLs); Instrumental activities of daily living (IADLs); Advanced activities of daily living (AADLs).

Table 2 - Prevalence of violence suffered among elderly community members according to functional capacity, Recife, Pernambuco, Brazil, 2016-2017

\begin{tabular}{|c|c|c|c|c|c|c|}
\hline \multirow[b]{2}{*}{ Variables } & \multicolumn{2}{|c|}{ BADLs } & \multicolumn{2}{|c|}{ IADLs } & \multicolumn{2}{|c|}{ AADLs } \\
\hline & $\begin{array}{c}\text { D } \\
\text { n (\%) }\end{array}$ & $\begin{array}{c}\text { I } \\
\text { n (\%) }\end{array}$ & $\begin{array}{c}\text { D } \\
\text { n (\%) }\end{array}$ & $\begin{array}{c}\text { I } \\
\text { n (\%) }\end{array}$ & $\begin{array}{c}\text { LA } \\
\text { n (\%) }\end{array}$ & $\begin{array}{c}\text { MA } \\
\text { n (\%) }\end{array}$ \\
\hline \multicolumn{7}{|c|}{ Psychological violence } \\
\hline Without violence & $15(15.3)$ & $83(84.7)$ & $57(57.6)$ & $42(42.4)$ & $44(44.4)$ & $55(55.6)$ \\
\hline With violence & $10(18.2)$ & $45(81.8)$ & $26(48.1)$ & $28(51.9)$ & $28(50.9)$ & $27(49.1)$ \\
\hline$p$ value & \multicolumn{2}{|c|}{$0.644^{*}$} & \multicolumn{2}{|c|}{$0.263^{*}$} & \multicolumn{2}{|c|}{$0.441^{*}$} \\
\hline \multicolumn{7}{|c|}{ Minor physical violence } \\
\hline Without violence & $23(15.6)$ & $124(84.4)$ & $80(54.4)$ & $67(45.6)$ & $69(46.6)$ & $79(53.4)$ \\
\hline With violence & $02(28.6)$ & $05(71.4)$ & 03 (42.9) & $04(57.1)$ & $04(57.1)$ & $03(42.9)$ \\
\hline$p$ value & \multicolumn{2}{|c|}{$0.318^{* *}$} & \multicolumn{2}{|c|}{$0.704^{* *}$} & \multicolumn{2}{|c|}{$0.707^{* *}$} \\
\hline \multicolumn{7}{|c|}{ Greater physical violence } \\
\hline Without violence & 25 (16.6) & $126(83.4)$ & $82(54.3)$ & $69(45.7)$ & $71(46.7)$ & $81(53.3)$ \\
\hline With violence & $01(25.0)$ & $03(75.0)$ & $02(50.0)$ & $02(50.0)$ & $03(75.0)$ & $01(25.0)$ \\
\hline$p$ value & \multicolumn{2}{|c|}{$0.524^{* *}$} & \multicolumn{2}{|c|}{$0.624^{* *}$} & \multicolumn{2}{|c|}{$0.346^{* *}$} \\
\hline
\end{tabular}

Note: * Pearson's chi-square test; ** Fisher's exact test; D - Dependent; I Independent; MA- more active; LA - less active; The basic activities of daily living (BADLs); instrumental activities of daily living (IADLs); Advanced activities of daily living (AADLs).

Table 3 - Variables associated with functional dependence through adjusted logistic regression, Recife, Pernambuco, Brazil, 2016-2017

\begin{tabular}{|c|c|c|c|}
\hline Variables & OR & $\mathrm{Cl}$ & $p$ value \\
\hline \multicolumn{4}{|l|}{ BADLs } \\
\hline \multicolumn{4}{|l|}{ Marital status } \\
\hline With companion & 5.100 & $1.460-17.811$ & 0.011 \\
\hline Without companion & 1.000 & - & - \\
\hline \multicolumn{4}{|l|}{ IADLs } \\
\hline \multicolumn{4}{|l|}{ Age } \\
\hline $60-70$ years & 1.000 & - & - \\
\hline$>70$ years & 2.565 & $1.209-5.442$ & 0.014 \\
\hline \multicolumn{4}{|c|}{ Know how to read and write } \\
\hline Yes & 1.000 & - & - \\
\hline No & 6.511 & $2.741-15.467$ & $<0.001$ \\
\hline \multicolumn{4}{|l|}{ Physical work activity } \\
\hline Yes & 1.000 & - & - \\
\hline No & 3.830 & $1.284-11.423$ & 0.016 \\
\hline \multicolumn{4}{|l|}{ AADLs } \\
\hline \multicolumn{4}{|l|}{ Age } \\
\hline $60-70$ years & 1.000 & - & - \\
\hline$>70$ years & 2.518 & $1.277-4.965$ & 0.008 \\
\hline \multicolumn{4}{|l|}{ Physical work activity } \\
\hline Yes & 1.000 & - & - \\
\hline No & 3.786 & $1.318-10.877$ & 0.013 \\
\hline
\end{tabular}

Note: OR - odds ratio; CI - Confidence interval; BADLs - Basic activities of daily living; IADLs - In strumental activities of daily living; $A A D L s$ - Advanced activities of daily living.
Table 3 shows the multiple logistic regression model for functional dependence, in which only the following variables were included: marital status, age, knowing how to read and write and physical work activity. The data allow us to infer that individuals with relationships are 5.1 times more likely to have functional dependence for BADLs.

Regarding IADLs, the elderly over 70 years of age, who do not know how to read or write and who do not carry out work activities, have, respectively, 2.565, 6.511 and 3.830 more likely to have dependence for these activities.

Considering the AAVDs, elderly people over 70 years old and who do not work have an increased (2.518 and 3.786, respectively) the probabilities of dependence in these advanced activities.

\section{DISCUSSION}

The characterization of the sample with regards to sociodemographic data showed a predominance of female people, without marital relationship, without exercising work activity and with an average income of one minimum wage. The predominance of females is a fact that reflects the higher life expectancy of women, with a longer survival, around 5 to 7 years, when compared to men, a process known as the feminization of old age ${ }^{(11)}$. 
However, the higher life expectancy of the elderly is linked to additional years with lower quality of life, greater fragility and increased risk of functional dependence. And when this profile is added to the effects of sociodemographic variables, such as lower education, living alone, having to care and needing care, the quality of life of women tends to decline ${ }^{(3)}$. It is worth mentioning that the increased risk of dependence associated with these sociodemographic variables can cause vulnerability to situations of violence.

In this sense, considering the dependence for less complex activities, there was a significant association for women, without a companion. Elderly people without a partner showed a reduction in functional capacity compared to those with partners, so they have an increased risk of becoming dependent ${ }^{(18)}$. Thus, there are chances that these elderly people are exposed to mistreatment, since they need someone else to assist them in their daily activities.

Regarding marital status, the elderly who do not have a marital relationship are more dependent for IADLs, corroborating the study carried out in the municipality of Campina Grande-PB, with 242 elderly people ${ }^{(19)}$. On the other hand, in this study, the elderly with a marital relationship have 5.1 times the probability of presenting functional dependence for BADLs, refuting the reference in the literature. Given the above, depending on the conjuncture in which the elderly person lives, they may become more dependent on their spouse to perform basic activities, which can generate overload and stress on them. This scenario can be conducive to situations of psychological violence that will impact the quality of life of the elderly.

In relation to the elderly over 70 years of age, who do not know how to read or write, without a marital relationship and without work activity, they were more dependent on activities of intermediate complexity and those of advanced complexity. In this context, schooling is an important factor regarding activities of intermediate complexity. As noted in this study, the data reveal that elderly people who cannot read or write are 6.5 times more likely to be dependent for IADLs.

In this sense, a study carried out in São Paulo-SP, with 1,188 elderly people, revealed that those with limited education were 10.1 times more likely to have compromised scores for cognitive status, functional skills and frailty, when compared to elderly people with greater schooling, who had 4.6 times the probability of the same bad scores ${ }^{(20)}$. That is, the more limited the education, the greater the probability of obtaining bad scores. In addition to this discussion, an investigation carried out in Pelotas-RS with 1,340 elderly people showed that low education has a negative effect on the performance of IADLs for the elderly ${ }^{(21)}$. Given this information, since the elderly need someone else to manage their finances, which is part of IADLs, they are susceptible to financial violence.

IADLs and AADLs are activities that, for the elderly, present a certain degree of complexity, especially for those who already have some health compromise. However, what is clear is that IADLs have a higher degree of complexity than BADLs, mainly due to their character of social involvement. Thus, many elderly people are able to perform all tasks within their own home; however, if it is necessary to do any activity that requires social contact outside the premises in which they are used, they feel unable ${ }^{(3)}$.

However, the greater degree of complexity to perform activities of daily living may result in the need for help, and the elderly may be more vulnerable to various situations. Following this premise, studies show that elderly people who do not work or are in an advanced senescence process have a greater dependence to perform activities of daily living, increase the burden of caregivers and, with this, can increase the probability of suffering abuse, mistreatment and/or violence ${ }^{(22-24)}$.

Regarding violence and the analysis of functional capacity for BADLs, it was demonstrated that violence (psychological, minor physical and major physical) predominated in elderly people with functional dependence for these activities. Authors ${ }^{(25)}$ report that dependence for activities of daily living was a decisive factor for the occurrence of violence in the elderly. A study conducted in Colombia, with the participation of 23,694 elderly people, found an association between functional capacity and elder mistreatment ${ }^{(26)}$, which demonstrates how much functional capacity can determine the occurrence of violence in the elderly population.

However, in the present study, considering the analysis of functional capacity for activities of intermediate complexity in relation to violence, no association of any type of violence with dependence for these activities was identified. These data oppose, in part, the findings of a systematic review ${ }^{(27)}$ whose conclusion is that the greater the degree of dependence of the elderly on BADLs and IADLs, the greater the risk of suffering all types of violence. In this sense, greater losses in activities of intermediate to low complexity provide greater opportunities for unmet needs, causing greater risk for manifestation of violence $^{(28)}$.

When analyzing the functional capacity for the activities of greater complexity in relation to the violence in question, it was evidenced that all the violence predominated in the elderly less active for these activities. In part, this can be explained by reports that the decrease in the frequency of AADLs is of a social nature, signalling the loss of motivation for social contacts, mobility problems and environmental inadequacy. Furthermore, engaging in these activities requires a certain degree of independence and autonomy, constituting a decline in physical health as a limitation for AADLs and increasing the chances of social isolation ${ }^{(29)}$.

In a study carried out in the emergency room, it was observed that the risk of violence increases 4.24 times the chance of developing frailty and that the latter influences the performance of daily activities among the elderly ${ }^{(30)}$. The analysis of these variables demonstrates the existence of a bidirectional relationship, in which the emergence of functional dependence can increase the risk of violence and, consequently, raise the level of this dependence.

Thus, these findings encourage the need for longitudinal investigations that reinforce the data found and address the gaps evidenced in this study, especially with regard to the relationship between the analysis of functional capacity for activities of intermediate complexity and violence; and also about the variables "marital status" and "functional dependence" for BADLs. 


\section{Study limitations}

This study presents a cross-section as a limitation, since data collection in a single moment does not make it possible to establish a causal relationship, but only to identify associated factors.

\section{Contributions to the area of Nursing, Health or Public Policy}

Identifying the level of functional capacity of the elderly makes it possible to understand the vulnerability of this individual to violence, allowing health professionals to build their care planning based on the real needs of the functionality of this elderly person and manage to prevent violence. In addition, the data shown in this work denote the need to assess functional capacity during care for the elderly, in order to reduce exposure to violence.

\section{CONCLUSION}

The study's findings allow us to conclude that elderly people with relationships have greater functional dependence for basic activities; those with advanced age, who cannot read or work, are more dependent on instrumental activities. For advanced activities, dependency is more significant among elderly people who do not work and are over 70 years old. With regard to violence, it is concluded that the dependence related to basic and advanced activities among the participants can favor violent outcomes, whether physical or psychological.

\section{REFERENCES}

1. Instituto Brasileiro de Geografia e Estatística (IBGE). Projeções e estimativas da população do Brasil e das Unidades da Federação [Internet]. Rio de Janeiro: IBGE; 2019 [cited 2020 Jun 03]. Available from: https://www.ibge.gov.br/apps/populacao/projecao/index.html?utm_ source=portal\&utm_medium = popclock\&utm_campaign = novo_popclock

2. Almeida TZS, Santos CA, Rocha SV, Pedreira RBS, Pinto Junior EP. Prevalência e fatores associados à incapacidade funcional em idosos residentes na zona rural. Rev Ciênc Méd Biol. 2016;15(2):199-203. doi: 10.9771/cmbio.v15i2.16996

3. Berlezi EM, Farias AM, Dallazen F, Oliveira KR, Pillatt AP, Fortes CK. Analysis of the functional capacity of elderly residents of communities with a rapid population aging rate. Rev Bras Geriatr Gerontol. 2016;19(4):643-52. doi: 10.1590/1809-98232016019.150156

4. Katz S, Akpom CA. A measure of primary sociobiological functions. Int J Health Serv. 1976;6(3):493-508. doi: 10.2190/uurl-2ryu-wryd-ey3k

5. Lawton MP, Brody EM. Assessment of older people: self-maintaining and Instrumental Activities of Daily Living. Gerontol. 1969;9(3):179-86. doi: 10.1093/geront/9.3_Part_1.179

6. Reuben DB, Solomon DH. Assessment in geriatrics: of caveats and names. J Am Geriatr Soc. 1989;37(6):570-2. doi: 10.1111/j.1532-5415.1989. tb05691.x

7. Pillemer K, Burnes D, Riffin C, Lachs MS. Elder Abuse: Global Situation, Risk Factors, and Prevention Strategies. Gerontologist. 2016;56(S2):S194-S205. doi: 10.1093/geront/gnw004

8. Dias VF, Araújo LSLR, Cândido ASC, Lopes AOS, Pinheiro LMG, Reis LA. Dados sociodemográficos, condições de saúde e sinais de violência contra idosos longevos. Rev Saúde Col UEFS. 2019;9:186-192. doi: 10.13102/rscdauefs.v9.3685

9. World Health Organization (WHO). Missing voices: views of older persons on elder abuse [Internet]. Geneva: WHO; 2002 [cited 2019 Nov 09]. Available from: https://apps.who.int/iris/bitstream/handle/10665/67371/WHO_NMH_VIP_02.1.pdf?sequence=1

10. World Health Organization (WHO). Global status report on violence prevention 2014 [Internet]. Geneva: WHO; 2014 [cited 2019 Nov 16]. Available from: https://www.who.int/violence_injury_prevention/violence/status_report/2014/en/

11. Lopes LGF, Leal MCC, Souza EF, Silva SZR, Guimarães NNA, Silva LSR. Violence against the elderly person. Rev Enferm UFPE. 2018;12(9):225768. doi: 10.5205/1981-8963-v12i9a236354p2257-2268-2018

12. Adib M, Esmaeili M, Zakerimoghadam M, Nayeri ND. Barriers to help-seeking for elder abuse: a qualitative study of older adults. Geriatr Nurs 2019;40(6):565-71. doi: 10.1016/j.gerinurse.2019.04.003

13. Oliveira EM, Silva HS, Lopes A, Cachioni M, Falcão DVS, Batistoni SST, et al. Atividades Avançadas de Vida Diária (AAVD) e desempenho cognitivo entre idosos. Psico-USF. 2015;20(1):109-20. doi: 10.1590/1413-82712015200110

14. Straus MA. Measuring intrafamily conflict and violence: the Conflict Tactics (CT) Scales. J Marriage Fam. 1979;41(1):75-88. doi: $10.2307 / 351733$

15. Lino VTS, Pereira SRM, Camacho LAB, Ribeiro Filho ST, Buksman S. Adaptação transcultural da Escala de Independência em Atividades da Vida Diária (Escala de Katz). Cad Saúde Pública. 2008;24(1):103-12. doi: 10.1590/S0102-311X2008000100010

16. Santos RL, Virtuoso Jr JS. Confiabilidade da versão brasileira da Escala de Atividades Instrumentais da Vida Diária. Rev Bras Promoç Saúde. 2008;21(4):290-96. doi: 10.5020/18061230.2008.p290

17. Hasselmann MH, Reichenheim ME. Adaptação transcultural da versão em português da Conflict Tactics Scales Form R (CTS-1), usada para aferir violência no casal: equivalências semântica e de mensuração. Cad Saúde Pública. 2003;19(4):1083-93. doi: 10.1590/ S0102-311X2003000400030

18. Matos FS, Jesus CS, Carneiro JAO, Coqueiro RS, Fernandes MH, Brito TA. Reduced functional capacity of community-dwelling elderly: a longitudinal study. Ciênc Saúde Colet. 2018;23(10):3393-401. doi: 10.1590/1413-812320182310.23382016 
19. Araújo GKN, Sousa RCR, Souto RQ, Silva Júnior EG, Eulálio MC, Alves FAP, et al. Functional capacity and depression in elderly. Rev Enferm UFPE. 2017;11(10):3778-86. doi: 10.5205/reuol.12834-30982-1-SM.1110201711

20. Brigola AG, Alexandre TS, Inouye K, Yassuda MS, Pavarini SCL, Mioshi E. Limited formal education is strongly associated with lower cognitive status, functional disability and frailty status in older adults. Dement Neuropsychol. 2019;13(2):216-24. doi: 10.1590/1980-57642018dn13-020011

21. Farías-Antúnez S, Lima NP, Bierhals IO, Gomes AP, Vieira LS, Tomasi E. Disability related to basic and instrumental activities of daily living: a population-based study with elderly in Pelotas, Rio Grande do Sul, 2014. Epidemiol Serv Saúde. 2018;27(2):e2017290. doi: 10.5123/ S1679-49742018000200005

22. Lino VTS, Rodrigues NCP, Lima IS, Athie S, Souza ER. Prevalence and factors associated with caregiver abuse of elderly dependents: the hidden face of family violence. Ciênc Saúde Colet. 2019;24(1):87-96. doi: 10.1590/1413-81232018241.34872016

23. Oliveira A, Nossa P, Mota-Pinto A. Assessing functional capacity and factors determining functional decline in the elderly: a cross-sectional study. Acta Med Port. 2019;32(10):654-60. doi: 10.20344/amp.11974

24. Instituto Brasileiro de Geografia e Estatística (IBGE). Pesquisa nacional por amostra de domicílios: síntese de indicadores 2014 [Internet]. Rio de Janeiro: IBGE; 2015 [cited 2020 Feb 24]. Available from: http:// biblioteca.ibge.gov.br/visualizacao/livros/liv65857.pdf

25. Maia PHS, Ferreira EF, Melo EM, Vargas AMD. Occurrence of violence in the elderly and its associated factors. Rev Bras Enferm. 2019;72(Suppl 2):64-70. doi: 10.1590/0034-7167-2018-0014

26. Ballesteros SM, Moreno-Montoya J. Individual - and state-level factors associated with functional limitation prevalence among Colombian elderly: a multilevel analysis. Cad Saúde Pública. 2018;34(8):e00163717. doi: 10.1590/0102-311X00163717

27. Alves CS, Serrão C. Risk factors for the occurrence of violence against the elderly: a systematic review. Pan Am J Aging Res. 2018;6(2):58-71. doi: 10.15448/2357-9641.2018.2.29964

28. Burnes D, Pillemer K, Caccamise PL, Mason A, Henderson CR, Berman J, et al. Prevalence of and risk factors for elder abuse and neglect in the community: a population-based study. J Am Geriatr Soc. 2015;63(9):1906-12. doi: 10.1111/jgs.13601

29. Souto JF, Ribeiro PCC, Souza LF. Atividades avançadas de vida diária: revisão de uma medida da capacidade funcional do idoso. Rev Kairós. 2017;20(3):407-25. doi: 10.23925/2176-901X.2017v20i3p407-425

30. Santos RC, Menezes RMP, Araújo GKN, Marcolino EC, Xavier AG, Gonçalves RG, et al. Frailty syndrome and associated factors in the elderly in emergency care. Acta Paul Enferm. 2020;33:eAPE20190159. doi: 10.37689/acta-ape/2020AO0159 